\title{
Roman Criminal Law in a Berlin Papyrus Codex (BGU IV 1024-1027)
}

James G. Keenan

jkeenan@luc.edu

Follow this and additional works at: https://ecommons.luc.edu/classicalstudies_facpubs

Part of the Ancient History, Greek and Roman through Late Antiquity Commons

\section{Recommended Citation}

Keenan, JG. "Roman Criminal Law in a Berlin Papyrus Codex (BGU IV 1024-1027)" in Archiv für Papyrusforschung 35, 1989.

This Article is brought to you for free and open access by the Faculty Publications and Other Works by Department at Loyola eCommons. It has been accepted for inclusion in Classical Studies: Faculty Publications and Other Works by an authorized administrator of Loyola eCommons. For more information, please contact ecommons@luc.edu. (c) (i) $\Theta$

This work is licensed under a Creative Commons Attribution-Noncommercial-No Derivative Works 3.0 License. (c) Walter de Gruyter GmbH, 1989. 


\title{
Roman Criminal Law in a Berlin Papyrus Codex (BGU IV 1024-1027)*)
}

\author{
James G. Keenan (Chicago)
}

\section{The Codex}

Of the statuary that has survived from Egypt's ancient dynasties, a familiar pose, whose prototype dates back to the Old Kingdom, is that of the scribe, sitting cross-legged with a papyrus roll spread open between his knees. Through Egypt's Ptolemaic and into its Roman period, although the scribe's position and posture may have changed, his use of the papyrus roll remained as before. But, beginning in the second century of Roman rule in Egypt, a new book form, the codex, identical in general design to the modern book, began to be developed and its use began to spread. Papyrus continued to provide the raw material for the pages of these codices; but where previously texts were (normally) written on a papyrus roll, from which they were on completion cut away, now blank-page "books" came to be fashioned, and writing followed the cutting up of the papyrus roll and the arranging of its sheets into book form.

This new book form was first used principally for literary and for religious texts; and according to one leading theory, Christian missionaries had much to do with the growing popularity of the new book format. The new format never replaced the papyrus roll as the chief receiver of ancient writing for everyday needs; but use of the codex was occasionally extended into areas normally the preserve of the papyrus roll. Noteworthy, for example, are the documentary codices which date to the sixth century A.D. and come from the middle Egyptian village of Aphrodito (near modern Assiut). Most of these codices are homogeneous in focus and in subject matter; they are the estate accounts of the village's most important landlord, Count Ammonius. There are other documentary codices, however, of other dates and provenances that contain more varied and more intrinsically interesting series of texts. One of these is a fourth-century codex from Hermopolis, a major find spot for papyri in middle Egypt.

This codex, now in East Berlin, was purchased for the Berlin Museum in 1902 by Otto Rubensohn. It was published by Wilhelm Schubart in 1912 as BGU IV 1024-1027. According to Schubart's counting, the codex contained 14 papyrus pages with 28 sides of writing; according to G. Poethke's more recent description of the codex's construction ${ }^{1}$ ) the 28 page sides of the codex are the product of a combination of four double leaves of

*) This paper is relatively unchanged from the form in which it was delivered before the Israel Society for the Promotion of Classical Studies, 21 May 1986. I am grateful to Professor Ranon Katzoff for the invitation to address the Society and to Dr.G. Poethke for his interest in publishing the paper in pages of Archiv für Papyrusforschung.

i) G. Poethke, Proc. XVIth Congr. Papyrology 457-62. 
papyrus, each giving four page sides (16 sides in all), and six single leaves, each giving two page sides (12 sides in all). Three of the single leaves do not appear to belong to the same gathering of the codex as the rest of the leaves; but the other three single leaves were sheaved into the gathering already made from the four double leaves. If my understanding of Poethke's description is correct, the single leaves have extrawide vertical flaps at the binding edge of the codex. These flaps may indicate that what are now single leaves were once double leaves that were part of the originally manufactured codex, but were subsequently amputated. Alternatively, these flaps may have served to facilitate and strengthen the stitching of the single leaves into the already-manufactured double-leaf gathering. It is fortunate that these technicalities of codex construction are not vital for that part of the codex where our primary interest lies. It is only the single leaf (pp. 5-6) inserted after codex p. 4 that would affect that part of the codex toward which my discussion is tending; and here the question is unimportant because of the apparent continuity of text from page 4 (the summary of a murder case) to page 5 (the judge's verdict on the case).

Schubart's edition, now nearly 75 years old, presents only the better-preserved pages of the Hermopolis codex $(3-8,15-16,22-23,26)-$ eleven of the 28-page total. It gives few details on the contents of the unpublished pages; they are described generally as accounts and it seems they are in very bad condition, for even many of the published pages show, from their editorial presentations, that they, too, are frequently damaged, especially toward the top. In those earlier days of papyrology, the practices and standards that Grenfell and Hunt had set by the example of their work on the Oxyrhynchus Papyri editions and other volumes in the Egypt Exploration Society series had not yet attracted universal imitation. Thus, in addition to his incompleteness in describing the codex, Schubart in his restorations and general treatment of the text was more cavalier than today's standards will allow. His proposals must sometimes be dismissed as unreliable. His editorial commentary is brief, limited for the most part to textual criticisms and suggestions, and to cross-references and citations. He does not provide, as nowadays required, a modern vernacular translation of the text.

In short, the codex is a document that begs a full, modern edition, but for now we must make do with what Schubart provided 75 years ago, supplemented by information recently presented by Poethke. From Schubart's edition, the codex proves to contain at least four discrete sets of documents. These I propose to summarize in brief, working from the back to the front of the codex and shortly to that part of the codex on which I should like to concentrate.

1. Pp.26-27 carry a single text, in many ways the most specific and detailed in the entire codex. It is an official letter from Flavius Domitius Asclepiades, apparently the provincial governor, to the leading citizens of Hermopolis. The letter rebukes them and their entire municipal council (Bovגevrígเov) for being in arrears in forwarding dues in kind (annona) that were assessed to them and ticketed for military units stationed in the desert

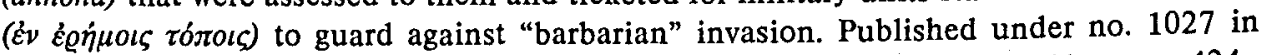
$B G U$ IV, a revised edition of these pages appears in Wilcken's Chrestomathie as no. 424.

2. Pp. 22-23: the upper halves of both pages are damaged and unedited. The thirteen lines from the lower part of p. 22 include four identifiable lines (stichoi) from the early books of the Iliad, with orders for their writing and with other instructions, for use in curing various medical problems like bleeding and certain gynecological pains. Page 23 continues the text of p.22 in the same hand and to the same purpose, with one more Homeric citation. But then, beginning at line 15 , a new text is begun, a prayer to the Sun for all kinds of blessings equal to those possessed by a number of archetypal figures, including 
the archangels Michael und Gabriel. The prayer is ultimately a prayer for favor ( $\chi a$ á $\iota \varsigma)$ from all men and women, but from one woman in particular; in sum, it is a love charm that ends with a model prayer with the name of the object of the prayer's affections to be supplied. "Grant me favor before all mankind and before all women, especially before Soand-So. Make me in her eyes handsome like Iao, wealthy like Sabaoth, beloved like Lailam, great like Barbara, honored like Michael, glorified like Gabriel, and I shall return the favor." Schubart classified the texts of pp. 22-23 as "Magic Texts" and, originally numbered 1026, they have been reprinted, in revised and improved editions, in Preisendanz's Papyri Magicae Graecae as XXIIa in vol.II.

3. Pages 15-16: each page contains two receipts, acknowledgements by councillors of Hermopolis of receipt of collections in kind (wine, meat, chaff) from a caretaker ( $\varepsilon \pi \iota-$ $\mu \varepsilon \lambda \eta \tau \dot{\eta}()$ named Aurelius Philammon as annona for military troops stationed in various distant posts, including Syene (Aswan) on the Nile's first cataract. Copies of each receipt were issued to a certain Silvanus, otherwise unidentified, who may be the military liaison for these transactions. One of the receipts, p. 15, lines $10 \mathrm{ff}$, reads (in translation): "Aurelius Philippos, son of Hermes, councillor of Hermopolis the most brilliant, to Aurelius Philammon, caretaker for the 3 rd indiction. I have received from you in Hermopolis four hundred measures of wine, sixty-eight pounds of meat, one thousand two hundred pounds of chaff" - totals are here repeated in abbreviation and cipher - "on condition that I credit you for them in Syene for the 3rd indiction."

Date and signatures follow. The four receipts are numbered 1025 in $B G U$ IV. The two receipts on p. 16 are reprinted in Wilcken's Chrestomathie as no. 422.

The presence of these receipts in the codex raises several questions. Most importantly, since the receipts are apparently not the copies issued to Silvanus nor the originals that should have gone to Philammon, they must be in fact triplicates retained by yet another party. If so, who? Apparently, the municipal council of Hermopolis itself or one of its leading representatives. If that is true, then a link between the receipts and the text preserved on codex pp. 26-27 emerges: that is, the Hermopolites had successfully collected their assigned quotas, but were delinquent in seeing to their proper delivery. The link between these two sets of texts, however, and the magical papyri of pp.15-16 and the last set of texts I am about to discuss remains an obscure and possibly insoluble mystery.

\section{The Law Cases}

This last set of texts to be summarized occupies pp.3-8 of the codex and contains remnants of at least seven different juristic decisions in criminal cases. They are all published under no. 1024 in $B G U$ IV. There is for each case a simple format or structure, the components of which vary in length from case to case. The basic presentation of each case is the

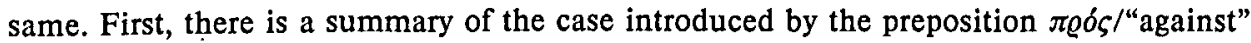
governing, in the accusative case, an anonymous description of the defendant. It is in fact remarkable, and no doubt pertinent to the gathering of cases preserved in $B G U 1024$, that the defendants and other parties appear more often than not unnamed; it is almost as if these are stock cases with stock participants (more on this below). After each case summary, the line of text is occupied by the words $\delta \dot{\eta} \gamma \varepsilon \mu \omega \dot{v}$, centered on the line and, in one instance (p. 3, line 19), further highlighted by the scribe's inclusion of a paragraphos. As with the anonymity of the parties to the cases, the title $\dot{\eta} \gamma \varepsilon \mu \dot{\omega} \nu$ seems also to have been purposefully used because it is so generic. There is no doubt, though, that it indicates the presiding magistrate of the cases and, according to fourth-century usage, points to someone of gubernatorial position, a governor of one of Egypt's fourth-century provinces, or 
perhaps the prefect of Egypt himself. With the noun hegemon, a verb suitable to the context, perhaps $\varepsilon i \pi \varepsilon v / " h e$ said", needs to be understood. What follows then is the magis-

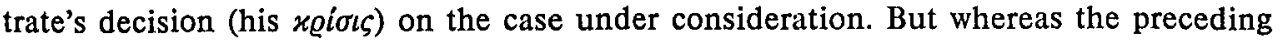
case summaries are presented in narrative form and in indirect discourse construction, the judge's decision is presented in oratio recta, as if the judge was actually facing the defendant and addressing him directly and squarely. Each krisis concludes with a condemnation of the defendant. The scribe marks the end of one case and the beginning of the next by inserting a paragraphos.

Here in brief, though with occasional comments, is what is to be found in the first six cases as presented in Schubart's edition.

1. Of the first case, only a few damaged lines of the judgement (only) survive. The verb

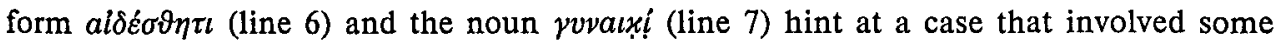
kind of domestic scandal. The name Zephyrios (line 10) recurs as the name of the presiding magistrate in the codex's seventh case.

2. The second case also concerns a woman. According to an early emendation of Schubart's text, she had, insofar as this case is concerned, the ironic name Sophronia, "Virtue," "Self-Control" (p. 3, lines 15,29). Sophronia, at any rate, seems to have been caught by her husband when she was with her lover. The husband pursues the lover with a sword; the lover escapes; the husband returns, overtakes his wive and kills her with the weapon he had wanted to use on her lover. The judge, in the much-damaged krisis, appears to restate the details of the case in his own words and to comment on some of its aspects; but the substance of his decision and the condemnatio of the defendant cannot be recovered. Paul's Sentences, an elementary law book with roots in the third century of the Roman Empire in the West, contains rules (Bk.2, ch.26) that might have applied to the $B G U 1024$ case. According to the Sentences, the husband was entitled to kill his wife's lover only if he caught them together in his own house; otherwise, he is forbidden to kill the lover and is, in any case, forbidden to kill his wife, but if he does so he "should be punished more leniently, for the reason that he committed the act through impatience caused by just suffering." But I can detect none of this in the damaged remains of the judgement of the $B G U 1024$ magistrate.

3. The third case summary is extremely short, taking up only two lines of text. From these two lines and from the judge's decision that follows, the case can be seen to concern the exhumation of a corpse that had been buried honorably at public expense. The judge waxes rhetorical, if puzzlingly illogical, in his krisis (p. 4, 11. 5 ff.): "I think you have the soul of a beast," he scoids the defendant, "not of a man; or rather, not even of a beast. For beasts attack men (sc. when they are alive), but spare them when they die." He continues to fulminate against the defendant in Greek that is full of problems, but which leads to a condemnation that is entirely unambiguous: "You shall receive capital punishment." The Greek probably stands for the Latin idiom capite puniri and indicates literally capital punishment by decapitation. As late as this decision is, it still calls to mind the well-known inscription from Nazareth ${ }^{1}$ ), undated but often assigned to the reign of the emperor Claudius. In that text, too, the disturbing of human burials brings with it capital punishment. The crime is there referred to as $\tau v \mu \beta \omega \varrho v x i a$ and suggests a possible alternate restoration in the Berlin codex, p. 4 , line 5.

4. The fourth case returns us to the general subject of the second, and possibly of the

1) Smallwood, Documents Illustrating the Reigns of Gaius, Claudius and Nero no. 377. 
first, case: a crime of passion. The charge here is "Against someone who loves his girlfriend too much." He catches her with another man, becomes enraged, and kills her with his sword. He soon repents the deed. The judge's decision seems to indicate that the defendant presented what would these days be called an insanity ( $\mu a v i a v$... Ě $\varrho \omega \tau o \varsigma)$, or dimished capacity, defense (p. 5 top). Apparently, the judge took that plea into account, for although he seems to disparage its relevance, he does not in his condemnation sentence the defendant to death. Rather the penalty is (line 6) the much-feared damnatio in metallum, a life sentence to hard labor in the mines. The condemned man is expected to learn a lesson from his deed ( $\mu \mu \nu \eta \sigma x o ́ \mu \varepsilon v o \zeta)$, but will apparently never get the chance to apply it.

5. Case five is against a soldier (p. 5, 1. 11) whose rank is garbled in the two-line case summary (lines 9-10). The charge seems rather vaguely put: he is "condemned for having a mother and (sc. her) daughter." The problem seems to be that the soldier has already warned about the incestuous "situation," but has proved implacable (cf. a' $\vartheta \varepsilon$ yia, line 17). The magistrate holds himself bound by the laws (lines 21-22) to condemn the defendant to two years' exile, the penalty that conforms to late imperial legislation on this crime.

6. The sixth case (p. 5 , lines $26 \mathrm{ff}$.) is diplomatically set off by a paragraphus, as expected from the set-off of other cases in this series. Unusual, however, in this summary is that it is also indented all along the lefthand margin toward the bottom of codex, page 5 . The case summary is brief (four lines), as is the judge's decision, insofar as it is preserved and presented. It takes up the last two lines of codex page 5, but may run over to the top of page 6 . Not much if anything can be made of this case and its disposition.

\section{The Seventh Case: Murder in Alexandria}

But this sixth, very briefest case and decision summary is followed immediately by the seventh, which is the longest and most detailed in the series. It begins toward the top of page 6 of the codex and runs all the way down to the bottom of page 8 . The case concerns a certain Diodemos, an Alexandrian senator, who had become enamored of a public prostitute (this picks up the eros-theme of the fourth case). Diodemos regularly enjoyed her companionship in the evening hours (for the editor's $\ddot{\eta} \sigma \vartheta \iota \varepsilon$ read, I am sure, $\ddot{\eta} \sigma \vartheta \eta$, from $\ddot{\eta} \delta o \mu a l)$. For motives unknown, he killed her. The authorities, here represented by one Zephyrios (the same man named as magistrate in the first case?), and probably here to be viewed as the prefect of Egypt, resident in Alexandria, learned of the murder. Zephyrios had Diodemos arrested and jailed, apparently standard procedure for decurions charged with capital crimes.

The next day (p. 6, lines $10 \mathrm{ff}$.), Diodemos' senatorial colleagues, in their morning salutation to Zephyrios at his private residence, petitioned for his release and, apparently also, for the dismissal of the case against him (lines 13-14). Although Zephyrios considered the petition unreasonable (äloyov, 15-16), he agreed to release Diodemos - falsely (ov่x $\dot{a} \lambda \eta \vartheta \dot{\eta} s)$ according to the codex's ex post facto record of the case. If we may speculate a bit on the drama of the scenario, it seems Zephyrios was trying to defuse a troublesome situation in the notoriously "tumultuous capital of Egypt" (Gibbon's label) and trying to buy time for a more careful consideration of a politically sticky case. Shortly after, therefore, Zephyrios reneged on his promise and argued for retaining Diodemos in jail.

The record of the hearing in this case begins at the top of codex page 7. The summary begins as an objective narrative of the trial, and the setting well conforms to what is known about cognitiones extra ordinem before Roman provincial governors. The prisoner is brought from jail and the hearing begins. He straightway admits to the murder. But the victim's mother, introduced in an almost comic stereotype as a penniless old hag $(\Theta \varepsilon$ - 


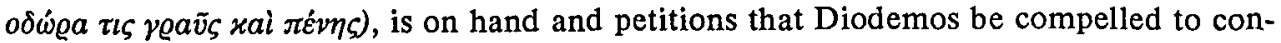
tribute to her support. Her presence and her petition (aj $\xi i \omega \sigma \iota)$ are first presented in the trial summary in narrative form; but then the lady is allowed to speak for herself: "For this reason I handed my daughter over to the procurer, that I myself might have food. Since therefore I have, by my daughter's death, been deprived of my support, I petition that I be given a moderate little woman's portion for my sustenance."

The magistrate's krisis follows (lines $19 \mathrm{ff}$.), presented here, as in the earlier summaries, in direct discourse. Though the text is often damaged or troublesome, the decision is clearly formulated in highly rhetorical style and is full of ironic antitheses. Though the victim had led a shameful life, she is to be pitied for having when alive sold herself to her customers like a corpse; her poverty drove her to this. Diodemos, on the other hand, had dishonored the senatorial order to which he belonged, and because of this is to be executed as a murderer. Theodora, the victim's mother, is to inherit 1/10 of Diodemos' estate; "the laws," according to the judge, "suggest this to me and a sense of clemency joins in inspiring the power of the laws."

A major problem with this case, as with the six that precede it, is whether the text gives a documentary record of an actual legal hearing and may therefore be construed as strictly authentic. Against this possibility stand the absence of absolute dating indicators and the complete anonymity of most of the parties involved in the earlier recorded cases; in a true documentary record we would expect their names to appear with some frequency even in the body of the reports. Even in the record of the Alexandrian murder case, where the names of the magistrate, the defendant, the victim's mother, but apparently not of the victim herself (unless it is to be restored, p.6, line 5), are given, the general format does not match that for the usual reports of proceedings, collected and analyzed some years ago by Revel Coles. Those reports that have survived are frequently private copies made from official records and so indicate this by an appropriate notation - $\dot{\varepsilon} \xi \delta \pi o \mu v \eta \mu a \tau \iota \sigma \mu \tilde{\omega} v-$ in their headings. In these authentic reports of proceedings, the presentation is throughout in oratio recta even though this need not prove they are verbatim records of their respective trials. A link between $B G U 1024$ to pseudo-documentary reports of proceedings like the so-called Acts of the Pagan Martyrs is a possibility that might be explored. With these, some of the $B G U$ cases share a flair for dramatic detail. Or the $B G U$ cases might be model cases, a collection of precedents, with some basis in the realities of late Roman practice. Or the $B G U$ cases might be partly authentic, and partly not. The brief identification of the defendant in each summary and the succinct indication of the charge against him may in fact be synopses of authentic records; but the main interest of the $B G U$ case summaries clearly resides in reporting to the fullest the words of the judge's decision, his krisis, and in these sections of each case summary there may lie a certain documentary authenticity. To put this another way, the $B G U 1024$ copyist, or his employer (whoever he may have been), was not so much concerned with the specifics of the crimes (the seventh case in this as in other respects is exceptional) as with the manner and substance of the magistrate's decisions for a variety of criminal cases. It may be significant that three of the cases are homicide cases with female victims of differing social, legal and personal statuses (wife, \#2, girlfriend, \#4, prostitute, \#7). If, however, $B G U 1024$ is some kind of variorum collection of related cases, it is puzzling not to find the homicide cases grouped together and ordered one after the other. Instead, other case summaries intervene and any sense of planned ordering in the arrangement of the cases is lost. 
4. Taubenschlag and the Codex

It is questions and problems like these that have, despite the inherent legal interest of $B G U 1024$ and the fascination of its individual cases, kept the text from being fully exploited and allowed it to fall into relative oblivion. It is a papyrus that is sometimes cited in book indices, but rarely discussed in their chapters. Nevertheless, shortly after its publication in 1912, $B G U 1024$ did elicit comment from reviewers of $B G U$ vol. IV and an early use of its cases was made by the Polish scholar, Rafael Taubenschlag, the principal force in the field of juristic papyrology for more than fifty years of the present century. Taubenschlag's early monograph, Das Strafrecht im Rechte der Papyri, published in 1916, incorporated all the initial reactions to and comments on $B G U 1024$ and was the first of a number of occasions on which Taubenschlag would appeal to $B G U 1024$ in his own juristic writings. He drew on it for articles that were later collected and reprinted (1959) in the two volumes of his Opera Minora and used it also in both editions of his The Law of Greco-Roman Egypt in the Light of the Papyri $(1944,1955)$, the standard work on the subject. Since Taubenschlag was the only scholar over the years to have made frequent reference to $B G U$ 1024 , it is opportune here to reintroduce and to sketch some of his main views on the text and to comment, however respectfully, on their shortcomings and problems. Those points that Taubenschlag has already contributed to my discussion are many, and here I must acknowledge my indebtedness. It is a few remaining issues, specifically those concerned with the Alexandrian murder case, issues that turn out to be of greater importance and wider implication, that I wish to point to and develop in the concluding section of this article.

As a starting point it is important to note that Taubenschlag held that $B G U 1024$ transmitted what he calls "Solomonic decisions" rather than protocols of actual legal proceedings. He endorsed Brassloff's view that although the case reports in $B G U 1024$ were literary rather than documentary in conception, they were nonetheless based on actual practice and could therefore be used with confidence in historical and juristic discussions. The proof of this was to be found, it seems, in the fact that the decisions and the corollaries of the cases were found to be in accord with imperial law as discoverable in the imperial law codes of late antiquity and in other relevant juristic sources. This tendency of Taubenschlag's writings to see imperial law at work and effective and frequently appealed to in papyri of Roman and Byzantine Egypt is one that Professor A. Arthur Schiller called seriously into question toward the end of his own long and distinguished career. Schiller told me once that he found Taubenschlag's picture "just too slick" and in need of thorough reappraisal. Let's first look at the laws that Taubenschlag saw operating in the report of the Alexandrian murder case.

One imperial law that Taubenschlag adduces in discussing the Alexandrian murder case is $C J 11.41(40)$.6. This is a constitution of A. D. 428 and therefore later than the criminal cases of the $B G U$ papyrus codex. By this law, among other rulings, a father who had handed his daughter over to prostitution lost his paternal power (patria potestas) over her and was forbidden to profit from the results of her endeavors. Taubenschlag implies some link between this law and the mother/daughter relationship in the Alexandrian murder case, though he acknowledges, as he must, that the law concerns fathers and daughters, not mothers and daughters. Roman law had, of course, of old validated the institution of patria potestas, but it never, not even by the end of antiquity, developed a parallel legal institution of "mother's power," materna potestas. Nevertheless, despite the late date of the law, Taubenschlag's reference to it is not ill-conceived, though a curious misinterpretation kept him from applying the full logic of the law to the case reported on the papyrus. 
Taubenschlag, for some reason - possibly to legitimate the mother's claim to income lost through her daughter's death - held that one could not in fact tell from the papyrus whether the mother was responsible for handing her daughter over to prostitution. But page 7, lines 13-15, presented as the mother's own words, are quite clear on her responsibility: she did it, though under allegedly strong duress, that is, in order to survive.

Despite such pressing circumstances, a law anticipatory or analogous to $C J 11.41 .6$ might have deprived the mother of claims to economic compensation from her daughter during the daughter's lifetime and from her murderer after her death. These are claims to which, according to Taubenschlag, the mother was entitled by other laws, to wit, the nomoi cited by the magistrate at p. 8, lines 19 and 20 . Taubenschlag presents for comparative purposes paragraph 36 of the Gnomon of the Idios Logos, by which $1 / 10$ of a murderer's estate was to be turned over to the victim's children; this is a rule dating to the 12 th regnal year of Antoninus Pius, A.D. 148/49. Once again, the "fit" to the present case is not precise, since in the Alexandrian murder case it is not children, but the victim's mother who is making and receiving a claim. Taubenschlag is therefore, it seems, inclined to see in the nomoi of $B G U 1024$, case 7 (note the plural number, however), reference to a specific

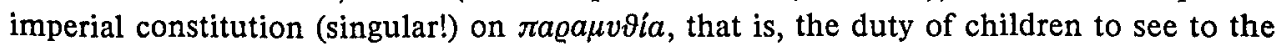
support of parents in need. This law would have been restricted in application to Egypt and would be otherwise unattested, apart from its citation in $B G U 1024$. The possibility that the $B G U 1024$ magistrate is making a general rather than a particular reference to laws or customs is not considered.

The most important issue is saved for last. Citing Wenger's earlier views, Taubenschlag concluded that $B G U 1024$ proved that condemnation to the mines was the penalty for murder committed in a rage (case 4 ) and that the penalty for ordinary homicide was crucifixion (case 7). Moreover, the latter case (case 7) established that the defendant's privileged status had had, contrary to expectation, no effect on his punishment. The crucial locus is p. $8,11.8-11$.

What Taubenschlag had in mind here was the so-called dual-penalty system, whereby under the Roman Empire different sets of criminal penalties were legislated for people of higher status (the honestiores) and for people of lower status (the humiliores). The details of the development and the hardening of the system are set out in Peter Garnsey's book, Social Status and Legal Privilege in the Roman Empire. As time wore on, penal laws grew harsher, and penalties formerly reserved for slaves came to be applied to low-class citizens; honestiores were subject to gentler and more dignified penalties.

Thus the surprise at seeing Diodemos, an Alexandrian senator, condemned to the cross in $B G U 1024$. But the surprise is unnecessary, because the key line (p. 8, line 10$)$ says nothing whatsoever about crucifixion. Rather, Diodemos is to be executed (cf. the verb xata-

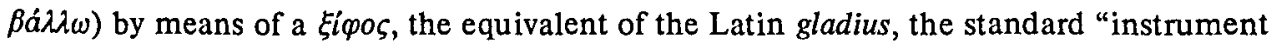
of civilian execution" in the Roman Empire. The penalty here is evidently one of death by decapitation. Earlier in the Roman Empire, Diodemos' decurial status would have saved him from execution for his crime; now, in the fourth century, it saves him, not from execution, but from a humiliating death by crucifixion (Pauli Sent. 5.23.1); or, following the abolition of crucifixion by Constantine, from the apparently even more excruciating torture of death by the "fork" (furca) or by exposure to wild beasts.

It is ironic, therefore, that in questioning Taubenschlag's general posture on the effectiveness of imperial law in Egypt, and in criticizing his interpretation of the laws at work in the Alexandrian murder case, I should end by presenting him with a reading of the case in which the expectations of late imperial law are, in the magistrate's krisis, satisfactorily met. 


\section{Conclusion}

So much more could be said about this case, and about the rest of the codex. Here I can only hope to have given a glimpse at a fascinating series of texts and to have reintroduced for scholarly consideration documents too long neglected and forgotten. It is heartening to learn that shortly the entire codex will receive from Professor Sijpesteijn and Dr. Poethke the full modern edition and commentary it merits. The codex is a lens through which many aspects of the late Roman Empire - legal, social, religious, fiscal, military - can be perceived; but it needs a good deal more polishing and cleaning before it can give us a sharper view of that critical century in world history. 